\title{
Pengaruh Penambahan Molase pada produksi Bioethanol dari Limbah Padat Industri Pati Aren
}

\author{
Effect of Addition of Molasses on Bioethanol Production from \\ Palm Starch Industrial Solid Waste
}

\author{
Dewi Astuti Herawati*1 \& D. Andang Arif Wibawa ${ }^{2}$ \\ ${ }^{1}$ Program Studi S1 Teknik Kimia, Fakultas Teknik \\ ${ }^{2}$ Program Studi D4 Analis Kesehatan, Fakultas Ilmu Kesehatan \\ Universitas Setia Budi Surakarta \\ J1. Let. Jend. Sutoyo, Mojosongo, Surakarta, 57127, Jawa Tengah, Indonesia \\ *Corresponding Author: dewitkusb@gmail.com
}

Received: Agustus 25, 2019; Revise: October 21., 2019; Accepted: November 8, 2019

DOI : https://doi.org/10.31001/biomedika.v12i2.619

\begin{abstract}
ABSTRAK
Penelitian ini telah dilakukan untuk mengetahui pengaruh penambahan molase terhadap produksi bioetanol dari limbah padat industri pati aren. Tahapan penelitian ini meliputi persiapan bahan baku, delignifikasi limbah padat pati aren, analisis kadar lignin, produksi enzim, fermentasi anaerob dan analisa kadar etanol. Delignifikasi limbah padat pati aren menggunakan larutan $\mathrm{NaOH} \mathrm{3 \%}$. Produksi enzim dihasilkan dari jamur A. Niger dan Trichoderma sp. Fermentasi menggunakan 5 gram sampel hasil delignifikasi ditambahkan larutan nutrisi, gabungan enzim selulase dari A. niger dan Trichoderma sp. dengan perbandingan (1:2), larutan molase $35 \%$ dan Saccharomyces cereviseae dari ragi roti. Analisis kadar etanol dilakukan setiap hari hingga hari ke-6. Delignifikasi menggunakan larutan $\mathrm{NaOH} 3 \%$ dapat menurunkan kadar lignin pada sampel $17,15 \%$. Penambahan molase mengandung gula 35\% sebagai sumber gula pada limbah padat pati aren akan meningkatkan kadar bioethanol dari 0,0904\% menjadi 3, $5407 \%$, sedangkan. molase dengan kadar gula $40 \%$ menghasilkan kadar bioethanol lebih rendah. Semakin tinggi kadar gula akan diperoleh kadar bioethanol semakin tinggi, tetapi apabila kadar gula terlalu pekat mengakibatkan proses fermentasi lambat pada produksi bioethanol.
\end{abstract}

Kata kunci: bioetanol; molase; limbah padat pati aren; $\mathrm{NaOH}$; delignifikasi

\begin{abstract}
Research has been carried out to determine the effect of the addition of molasses to on bioethanol production from palm starch industrial solid waste. The stages of this research were the preparation of raw materials, delignification of palm starch solid waste, lignin content analysis, enzyme production, anaerobic fermentation and ethanol content analysis. Delignification of palm starch solid waste using $3 \% \mathrm{NaOH}$ solution. Enzyme production is produced from A. Niger and Trichoderma sp. Fermentation using 5 grams of delignified sample added a nutrient solution, a mixture of cellulase enzymes from A. niger and Trichoderma sp. by comparison (1: 2), molasses and Saccharomyces cereviseae. Analysis of ethanol levels was carried out every day until the 6th day. Delignification using $3 \% \mathrm{NaOH}$ solution can reduce the level of lignin samples up to $17.15 \%$. The addition of molasses containing 35\% sugar as a source of sugar in the palm starch solid waste will increase the levels of bioethanol from $0.0904 \%$ to 3, 5407\%, whereas molasses with 40\% sugar content results in lower bioethanol levels. The higher the sugar content, the higher the level of bioethanol, but if the sugar content is too concentrated, it causes a slow fermentation process in the production of bioethanol.
\end{abstract}

Key word: bioethanol; mollase; the palm starch industrial solid waste; $\mathrm{NaOH}$; delignification 


\section{PENDAHULUAN}

Pabrik pati aren di dusun Bendo, desa Daleman Kecamatan Tulung dengan rata-rata kapasitas produksinya 200 ton/tahun menghasilkan limbah padat $17.500 \mathrm{~kg}$ per hari sehingga perlu perlakuan khusus untuk mengurangi dampak negatifnya (Haryanto, 2015). Limbah padat memiliki kadar alfa selulosa yang tinggi sebesar 95,34\% (Sudarsono dkk., 2013). Bahan yang mengandung selulosa merupakan bahan baku bioetanol.

Bioetanol merupakan salah satu jenis energi terbarukan, diharapkan membantu pemenuhan energi pengganti minyak bumi. Bioetanol diproduksi melalui 3 tahapan yaitu hidrolisis, fermentasi dan pemurnian. Hidrolisis merupakan tahap pemecahan selulosa menjadi senyawa karbohidrat, sedangkan fermentasi merupakan tahapan pemecahan senyawa karbohidrat menjadi etanol. Tahap pemurnian dilakukan untuk memperbesar kadar alkohol yang diinginkan. Proses hidrolisis memiliki hambatan yaitu adanya struktur kristalin dan lignin, sehingga selulosa sulit untuk diuraikan (Judoamidjojo dkk.,1989). Hal ini menunjukkan bahwa limbah padat pati aren yang akan digunakan untuk produksi bioetanol perlu dilakukan pretreatment berupa delignifikasi. Delignifikasi merupakan proses penghancuran lapisan lignin yang melindungi selulosa. Delignifikasi merupakan proses penghancuran lapisan lignin yang melindungi selulosa sekaligus merusak strukturnya dan melepaskan senyawa karbohidrat. (Zheng et al., 2009). Salah satu larutan yang digunakan untuk delignifikasi lignoselulosa adalah larutan $\mathrm{NaOH}$
(Sahare et al, 2012). Larutan $\mathrm{NaOH}$ yang digunakan untuk mendelignifikasi merupakan larutan encer agar tidak merusak struktur selulosa dan hemiselulosa. Menurut Elwin (2014) bahwa delignifikasi pada tanaman eceng gondok dengan larutan $\mathrm{NaOH} 2 \mathrm{M}$ dapat menurunkan lignin sebesar $0,5 \%$.

Produksi bioetanol dengan

metode SSF (Simultaneous of Saccarification and Fermentation) memerlukan bantuan mikroorganisme untuk mengubah glukosa menjadi etanol. Metode SSF merupakan metode yang menggabungkan proses hidrolisis dan fermentasi sehingga lebih efektif dan efisien dari penggunaan alat. Menurut penelitian Herawati dkk (2016) fermentasi ampas aren dengan menggunakan metode SSF dan konvensional lebih efektif karena kadar etanol yang diperoleh dari metode konvensional mengalami penurunan sejak hari pertama hingga hari ke-5 sedangkan metode SSF diperoleh kadar etanol yang meningkat sejak hari ke-2.

Hasil penelitian terdahulu menunjukkan bahwa bioethanol hasil produksi fermentasi limbah padat pati arenn tidak optimal diduga disebabkan karena jumlah substrat yang tersedia belum mencukupi. Substrat berupa gula yang langsung dapat digunakan pada proses fermentasi. Molase merupakan hasil samping dari pengolahan gula kristal tebu. Kadar gula yang terdapat dalam molase sekitar 45 - 54,6 \%. Kadar gula dalam molase yang cukup tinggi berpotensi sebagai tambahan substrat gula dalam limbah padat pati aren. Perbaikan proses pada produksi bioetanol dari limbah padat aren dan molase diharapkan dapat memperbaiki 
mutu produk yang didapatkan Penelitian ini bertujuan mengetahui pengaruh penambahan molase terhadap produksi bioetanol dari limbah padat pati aren menggunakan metode SSF.

\section{METODE PENELITIAN}

\section{Peralatan dan Bahan}

Peralatan yang digunakan dalam penelitian ini adalah crusher, oven, Autoclave, neraca analitis, ayakan ukuran 40 mesh, shaker, centrifuge, peralatan gelas, Spektrofotometer UVVis kromatografi gas, inkas dan thermometer.

Bahan - bahan penelitian meliputi Limbah padat industri pati aren, Jamur Trichoderma sp., Jamur A. Niger, Saccharomyces cereviseae; media tumbuh Potato Dextrose Agar (PDA); $\left(\mathrm{NH}_{4}\right)_{2} \mathrm{SO}_{4} \quad(10 \mathrm{~g} / \mathrm{L})$, urea $(3 \mathrm{~g} / \mathrm{L})$, $\mathrm{CaCl} . \mathrm{H}_{2} \mathrm{O}(0,5 \mathrm{~g} / \mathrm{L}), \mathrm{KH}_{2} \mathrm{PO}_{4}(3 \mathrm{~g} / \mathrm{L})$, $\mathrm{MgSO}_{4} .7 \mathrm{H}_{2} \mathrm{O}(0,5 \mathrm{~g} / \mathrm{L}), 1$ liter akuades; $\mathrm{NaOH}$ p.a padat; Asam Sulfat; Alkohol $70 \%$; Benzene p.a; dan Tween 80 0,1\%.

\section{Pengambilan Sampel}

Sampel burupa serat limbah industri pati aren yang diambil secara acak dari tiaptiap industri kemudian dicampur dibersihkan, dikeringkan, diperkecil ukuran dan diayak lolos 40 mesh disediakan dalam jumlah yang cukup untuk penelitian

\section{Pretreatment Serat Aren}

Serbuk Sampel sebanyak 30 gram, larutan $\mathrm{NaOH} 3 \%$ (b/v) sebanyak 800 ml keduanya dimasukkan ke dalam Erlenmeyer $1 \mathrm{~L}$ yang dilengkapi dengan kondensor. Kemudian sampel dipanaskan secara langsung selama 90 menit dimulai dari waktu pertama sampel telah mendidih. Setelah itu, campuran didiamkan agar dingin kemudian dituang ke dalam kain untuk dinetralkan dengan cara dialiri air. Setelah sampel netral kemudian sampel dikeringkan pada oven. Sampel yang sudah melalui tahap pretreatment diuji kadar ligninnya menggunakan metode Klason (SNI 0492:2008).

\section{Tahap Produksi Bioetanol}

Sampel yang telah mengalami delignifikasi sebanyak 5 gram, larutan nutrisi steril sebanyak $100 \mathrm{~mL}$ dan molase sebanyak $35 \%$ ( v/v) dicampur dalam erlenmeyer $500 \mathrm{~mL}$. Enzim selulase produksi jamur $A$ niger dan Trichoderma $s p$ ditambahkan sebanyak $45 \mathrm{ml}$ dengan perbandingan 1: 2 (Herawati, dkk., 2016) dan ragi roti konsentrasi $0,8 \% \quad(\mathrm{~b} / \mathrm{v})$ (Kusmiati dan Arifin, 2010) ke dalamnya. Sampel tersebut difermentasi selama 7 hari dan setiap hari menganalisis kadar alkoholnya menggunakan Kromatografi gas. Melakukan percobaan yang sama dengan diatas tanpa penambahan molase dan tanpa sampel.

\section{HASIL DAN PEMBAHASAN}

\section{Pretreatment sampel (limbah ampas pati aren)}

Pretreatment adalah proses yang dilakukan untuk mempersiapkan bahan baku agar memenuhi kondisi yang diharapkan, yang dilakukan antara lain perlakuan fisik dan kimiawi (Mosier et al., 2005). Pengurangan ukuran dan pretreatment merupakan tahap awa yang diperlukan untuk bahan lignoselulosa. Perlakuan fisik meliputi pengeringan bahan baku, penggilingan dan penyesuaian ukuran yang dibutuhkan. Proses ini merupakan salah satu cara pretreatment secara fisika. 
Pretreatment secara fisika/mekanik ditujukan dalam rangka menurunkan ukuran partikel bahan baku. Cara tersebut diatas merupakan salah satu cara yang paling efektif untuk menaikkan aksesibilitas enzim ke dalam bahan lignoselulosa. Kelebihan metode ini adalah tidak menggunakan bahan-bahan kimia serta tidak meninggalkan residu berbahaya.

Menurut Taherzadeh dan Karimi, 2008 menyatakan bahwa proses penggilingan ini bertujuan untuk memperkecil ukuran partikel, mengubah ultrastruktur serta tingkat kristalinitas lignoselulosa. Perubahan tersebut berdampak pada peningkatan efektifitas enzim selulase pada bahan lignoselulosa.

Proses penggilingan ini dilakukan sebelum tahap hidrolisis enzimatik atau tahap pretreatment lainnya.

Preatreatment secara kimia dilakukan dengan cara delignifikasi limbah ampas pati aren menggunakan larutan $\mathrm{NaOH}$. Berdasarkan penelitian Sudarsono (2013) serat aren memiliki kandungan $\alpha$ selulosa sebesar 95,34\%. Kadar selulosa yang tinggi pada serat aren dapat dihidrolisis menggunakan enzim selulase dari jamur Trichoderma sp. (Hamelinck dkk. 2005). Namun limbah padat pati aren merupakan tanaman lignoselulosa sehingga ada beberapa penyusun tanaman tersebut diantaranya yaitu lignin, selulosa dan hemiselulosa.

Hal ini bertujuan untuk mengurangi kadar lignin pada limbah padat pati aren. Lignin dapat memperlambat penetrasi enzim, hal ini dikarenakan adanya ikatan silang dari struktur aromatik lignin dan berpengaruh pada proses hidrolisis dalam memproduksi glukosa.

Hasil delignifikasi ampas pati aren menunjukkan kadar lignin yang tersisa dalam sampel menurun 17,15\% yaitu dari kadar lignin 91,5364\% menjadi $75,8350 \%$ (Tabel 1).

Tabel 1. Kadar Lignin Ampas Pati Aren

\begin{tabular}{lcc}
\hline & $\begin{array}{c}\text { Sebelum } \\
\text { delignifikasi }\end{array}$ & $\begin{array}{c}\text { Sesudah } \\
\text { delignifikasi }\end{array}$ \\
\hline $\begin{array}{l}\text { Kadar } \\
\text { lignin }(\%)\end{array}$ & 91,5364 & 75,8350 \\
\hline
\end{tabular}

Proses delignifikasi merupakan proses saponifikasi terhadap ikatan intermolekular ester yang mengelilingi xilan, hemiselulosa dan komponenkomponen lainnya, seperti lignin dan hemiselulosa lainnya. Zheng et al, 2009 dalam penelitiannya menyatakan bahwa proses delignifikasi menyebabkan kerusakan terhadap struktur lignin dan melepaskan senyawa karbohidrat.

Penelitian ini menggunakan delignifikasi secara kimiawi yaitu metode alkali. Bahan pelarut yang digunakan yaitu $\mathrm{NaOH}$. Menurut Gunam dan Antara, 1999 menyatakan bahwa struktur lignin pada bagian kristalin dan amorf dapat dirusak dan diserang oleh larutan $\mathrm{NaOH}$ ini serta memisahkan sebagian hemiselulosa. Proses delignifikasi dengan larutan alkali biasanya menggunakan larutan $\mathrm{NaOH}$, $\mathrm{KOH}$ dan $\mathrm{NH}_{4} \mathrm{OH}$ hidroksida (Zhang et al, 2009; Wang et al, 2010). Menurut Widiasari (2011), $\mathrm{NaOH}$ dapat mendegradasi lignin dengan cara memutus ikatan silang ester pada lignin. Gambar 1 menunjukkan degradasi lignin menggunakan $\mathrm{NaOH}$.

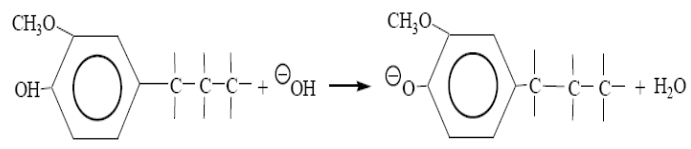

Gambar 1. Reaksi degradasi lignin menggunakan larutan $\mathrm{NaOH}$ pada proses pretreatment 
Metode pretreatment basa dalam pengolahan biomassa lignoselulosa menyebabkan dekristalisasi parsial selulosa, solvasi parsial hemiselulosa dan mengakibatkan selulosa membesar. Disamping itu juga menyebabkan perubahan struktur lignin dengan cara mendegradasi ester dan rantai samping glikosidiknya. Proses pretreatment basa dilakukan dengan cara biomassa direndam dalam larutan alkali pada kondisi tertentu.. Lignin dan zat inhibitor (misalnya garam, asam fenoloik, dan aldehid) pada proses perendaman alkali dapat dihilangkan dengan cara netralisasi. Proses ini dilakukan sebelum masuk tahap hidrolisis enzimatik.(Menon dan Rao 2012). Kelebihan pretreatment basa adalah lebih efektif dalam solubilisasi lignin daripada pretreatment asam akan tetapi kurang dalam mendegradasi selulosa dan hemiselulosa.

\section{Pengaruh Penambahan Molase terhadap Produksi Bioethanol}

Kadar glukosa dalam ampas aren yang digunakan untuk mengubah ke dalam etanol harus sesuai. Menurut Eka dkk (2009) kadar gula yang baik untuk proses fermentasi sebesar 10-18\%. Kadar gula yang tinggi dalam bahan akan menyebabkan efek buruk pada aktivitas dan pertumbuhan mikroorganisme. Kadar gula dalam bahan terlalu pekat mengakibatkan pertumbuhan mikroorganisme akan terhambat menyebabkan waktu untuk proses fermentasi menjadi lambat dan terdapat sisa gula yang tidak digunakan, Apabila kadar gula dalam bahan terlalu rendah maka proses fermentasi tidak berjalan dengan baik.

Analisa gula total dengan metode Nelson Somogy limbah padat aren memiliki kadar gula total sebanyak 0,904\%. Hal tersebut menyebabkan limbah padat aren perlu tambahan glukosa agar dapat terfermentasi dengan baik. Kadar gula reduksi semakin tinggi, maka semakin banyak yang dapat dimanfaatkan oleh khamir (S.cerevisiae) maka semakin tinggi pula kadar etanol yang dihasilkan. Penelitian ini sesuai dengan pendapat Winarti (1996), bahwa semakin banyak gula yang dapat dipecah oleh sel khamir menjadi bioetanol maka semakin tinggi pula konsentrasi bioetanol yang dihasilkan. Penelitian ini menggunakan molase $35 \%$ untuk penambahan kadar glukosa pada limbah padat aren menjadi $13 \%$.

Fermentasi molase kadar gula 40 $\%$ dilakukan dengan perlakuan yang sama tanpa menggunakan sampel limbah padat pati aren. Molase dan sampel yang difermentasi dianalisa kadar etanolnya menggunakan kromatografi gas dengan waktu pengamatan tiap hari sampai hari ke-6. Kadar bioetanol yang dihasilkan dipengaruhi oleh lama Fermentasi. Hasil fermentasi molase dan ampas pati aren dengan analisa kromatografi gas selama 6 hari berturut-turut (Tabel 2).

Tabel 2 menunjukkan bahwa fermentasi alkohol dengan subtrat molase kadar gula $40 \%$ menghasilkan bioethanol paling tinggi sebesar 0,7850 $\%$ sedangkan pada ampas pati aren dengan tambahan subtrat gula dari molase kadar gula $13 \%$ didapatkan kadar etanol lebih tinggi yaitu sebesar 3,5407\%. Fermentasi bioetanol dari ampas pati aren tanpa tambahan molase dihasilkan kadar ethanol yang hampir tidak ada yaitu paling tinggi sebesar $0,0940 \%$. Hasil penelitian menunjukkan bahwa penambahan molase $35 \%$ pada substrat ampas pati aren dapat meningkatkan kadar bioetanol sedangkan molase kadar gula 40\% kadar etanol lebih rendah. Kadar gula yang 
terlalu pekat dapat mengakibatkan laju fermentasi menjadi lambat, karena kandungan gula lebih banyak digunakan untuk reproduksi sel terlebih dahulu.

Tabel 2. Kadar Etanol pada Fermentasi Molase dan Ampas Pati Aren

\begin{tabular}{|c|c|c|c|}
\hline \multirow{2}{*}{$\begin{array}{c}\text { Hari } \\
\text { ke- }\end{array}$} & \multicolumn{3}{|c|}{ Kadar Ethanol ( \% ) } \\
\hline & $\begin{array}{l}\text { Molase } \\
\text { ( kadar } \\
\text { gula } \\
40 \% \text { ) }\end{array}$ & $\begin{array}{c}\text { Ampas } \\
\text { pati aren } \\
\text { dan } \\
\text { molase } \\
35 \% \\
\text { (kadar } \\
\text { gula total } \\
13 \%)\end{array}$ & $\begin{array}{l}\text { Ampas } \\
\text { Pati Aren } \\
\text { (kadar } \\
\text { gula total } \\
0,904 \% \text { ) }\end{array}$ \\
\hline 1 & 0,0000 & 0,0000 & 0,0000 \\
\hline 2 & 0,6671 & 0,7866 & 0,0000 \\
\hline 3 & 0,6961 & 1,2617 & 0,0500 \\
\hline 4 & 0,7850 & 3,5407 & 0,0940 \\
\hline 5 & 0,6836 & 1,3544 & 0,0200 \\
\hline 6 & 0,0000 & 0,0000 & 0,0000 \\
\hline
\end{tabular}

Berdasarkan Tabel 2 dapat diketahui bahwa kadar etanol pada ampas aren paling tinggi di hari ke-4. Hari ke-1 terlihat bahwa proses fermentasi ampas aren belum menghasilkan etanol. Hal ini disebabkan Saccharomyces cereviseae masih pada tahap penyesuaian diri dengan substrat yang akan diubah menjadi bioetanol. Jika kadar bioetanol yang terkandung di dalam substrat tinggi maka justru akan berdampak buruk terhadap pertumbuhan Saccharomyces cerevisiae, pada kadar alkohol 2,5\% pertumbuhan Saccharomyces Cerevisiae akan terhambat. Kadar alkohol yang diperoleh dari fermentasi kulit nanas sebesar 2,25\% pada hari ke-3 dan mengalami penurunan pada hari ke-4 dengan kadar 1,71\% (Azizah dkk 2012). Setelah hari ke-4 produksi bioetanol mulai menurun yaitu pada hari ke-5 hingga hari ke-6 terus mengalami penurunan. Hal itu disebabkan karena pada hari ke-4 kadar bioetanol sudah mencapai lebih dari 2,5\% sehingga kemungkinan pada saat itu pertumbuhan Saccharomyces cereviseae mulai terhambat dan mengalami penurunan. Gambar 2 menunjukkan kurva pertumbuhan Saccharomyces cereviseae pada penelitian ini ditunjukkan pada

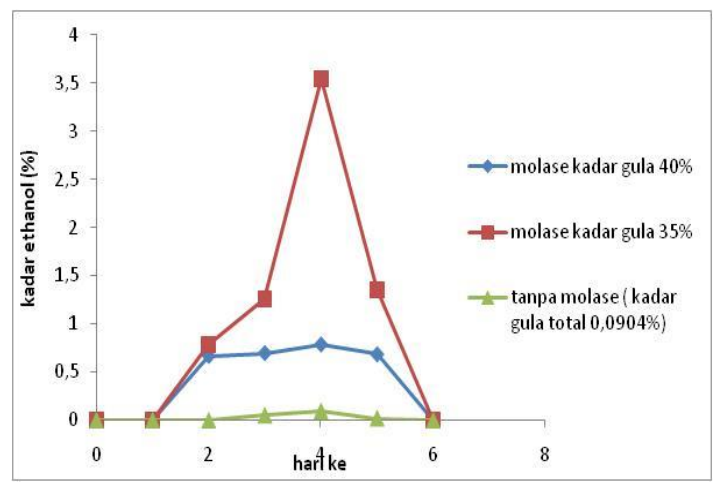

Gambar 2. Kurva Pertumbuhan Saccharomyces cereviseae pada berbagai kadar gula yang ditunjukkan dengan produksi etanol.

Fermentasi ampas aren dan molase ini bergantung pada pertumbuhan Saccharomyces cereviseae. Awalnya Saccharomyces cereviseae sedang berada pada fase adaptasi dengan kondisi subtrat. Setelah melalui fase adaptasi Saccharomyces cereviseae telah menemukan nutrisi yang tepat yang terdapat pada sampel maupun blanko sehingga mampu memproduksi etanol secara bertahap. Hal itu dikarenakan Saccharomyces cereviseae berada pada fase pertumbuhan dahulu hingga mengalami fase logaritmik yaitu fase dimana Saccharomyces cereviseae mampu memproduksi etanol dalam jumlah lebih banyak dari pada awal pertumbuhan. Kandungan glukosa dalam substrat akan berkurang seiring bertambahnya etanol sehingga kemampuan Saccharomyces cereviseae 
pun menurun karena nutrisi sudah mulai habis. Hal ini disebut fase menuju kematian. Jika nutrisi serta glukosa dalam substrat sudah habis maka Saccharomyces cereviseae akan mengalami kematian karena tidak memiliki makanan untuk melakukan metabolisme.

\section{KESIMPULAN}

Produksi bioetanol sangat dipengaruhi oleh substrat yang digunakan, penambahan molase sebagai sumber gula pada subtrat pati aren akan meningkatkan kadar bioethanol dari 0,0904\% menjadi 3, $5407 \%$ dengan penambahan molase kadar gula $35 \%$. Molase dengan kadar gula $40 \%$ menghasilkan kadar bioethanol lebih rendah. Semakin tinggi kadar gula akan diperoleh kadar bioethanol yang semakin tinggi, akan tetapi apabila kadar gula terlalu pekat mengakibatkan proses fermentasi lambat.

\section{UCAPAN TERIMAKASIH}

Ucapan terimakasih disampaikan kepada Universitas Setia Budi yang telah mendanai penelitian ini melalui Hibah Penelitian Terapan Internal tahun 2018.

\section{DAFTAR PUSTAKA}

Azizah, N, A N Al-Barrii dan S Mulyani. 2012. Pengaruh Lama Fermentasi Terhadap Kadar Alkohol, pH, Dan Produksi Gas Pada Proses Fermentasi Bioetanol Dari Whey Dengan Subtitusi Kulit Nanas. Research Note. Jurnal Teknologi Aplikasi Pangan. Vol. 1 No. 2 (72-77)

Elwin, Lutfi, M., dan Hendrawan, Y. 2013. Analisis Pengaruh Waktu Pretreatmet dan Konsentrasi $\mathrm{NaOH}$ terhadap Kandungan Selulosa, Lignin, dan Hemiselulosa Eceng Gondok Pada Proses Pretreatment Pembuatan Bioetanol. Keteknikan Pertanian Tropis dan Biosistem, 2(2): 104-110
Eka P, dan Halim Amran, 2002, Pembuatan Bioethanol dari Nira Siwalan secara Fermentasi Cair menggunakan Fermipan, Reaktor Guidelines.

Gunam, I.B.W., dan Antara N.S. 1999. Study on Sodium Hydroxide Treatment of Corn Stalk to Increase Its Cellulose Saccharification Enzymatically by Using Culture Filtrate of Trichoderma reesei. Gitayana. Agric. Technol. J. 5 (1):34-38

Hamelinck, C.N., G. van Hooijdonk, dan A.P.C. Faaij. 2005. Ethanol from lignocellulosic biomass: Techno-economic performance in short-, midle- and long-term. Biomass and Bioenergy 28: 384-410.

Haryanto, V. I. 2015. Pemanfaatan Limbah Cair Industri Tepung Aren dan Mikroorganisme Lokal sebagai Larutan Nutrisi Terhadap Pertumbuhan dan Hasil Tanaman Baby Kailan (Brassica oleracea) dengan Sistem Hidroponik. Universitas Sebelas Maret

Herawati, D A; Kusumawardhani , E; Puspawati N, 2016. "Pemanfaatan Limbah Ampas Pati Aren Menjadi Bioetanol Secara Enzimatis Metode Konvensional dan SSF", Simposium Nasional RAPI XV Tahun 2016 FT UMS.

Judoamidjojo, R.M., E.G. Sa'id, dan L.Hartoto. 1989. Biokonversi. Departemen Pendidikan dan Kebudayaan, Dirjen Dikti, Pusat Antar Universitas Bioteknologi Institut Pertanian Bogor.

Kusmiyati, dan Arifin, A. N. 2010. Konversi Umbi Iles-Iles Menjadi Bioetanol Dengan Metode Konvensional dan SSF (Sakarifikasi dan Fermentasi Secara Serentak). RAPI IX (pp. K-116 - K123). Surakarta: Universitas Muhammadiah Surakarta.

Menon V dan Rao M. 2012. Trends in bioconversion of lignocellulose: Biofuels, platform chemicals \& biorefinery concept. Progress in Energyand Combustion Science 8(4): 522-550.

Mosier, N.S, Dale, B.E, Wyman C E dan, Elander S. 2005. Features of promising technologies for pretreatment of lignocellulosic biomas Bioresource Technology 96 , pp. 673-686

Saharee, P., Singh, R., Laxman, S., dan Rao, M., (2012). Effect Of Alkali Pretreatment On The Structural Properties And Enzymatic Hydrolysis of Corn Cob. Appliedbiochemistry and biotechnology. 168(7),1806-1819

SNI 0492 (2008). Pulp-Cara Uji Kadar Lignin Metode Klason.

Sudarsono, Huda, S., Yuniwati, M., \& Purnawan. (2013). Pemanfaatan Limbah Serat Pati 
Aren Sebagai Material Komposit Poliester. Yogyakarta: Institut Sains \& Teknologi AKPRIND.

Taherzadeh MJ dan Karimi K. 2008. Pretreatment of lignocellulosic wastes to improve ethanol and biogas production: $A$ Review. Int. J. Mol. Sci. 9: 1621-1651.

Wang, Z., Keshwani, D.R., Redding, A.P., dan Cheng, J.J., 2010. Sodium hydroxide pretreatment and enzymatic hydrolysis of coastal Bermuda grass. BioresourceTechnology. 101, pp.35833585

Widyasari, R.2011. Pengaruh Konsentrasi Enzim Selulase untuk Menghidrolisis Selulosa dan Hemiselulosa TKKS menjadi Gula Reduksi sebagai Bahan Baku Bioethanol,., Skripsi Universitas Lampung, Bandar Lampung.

Winarti, S.. 1996. Pengaruh Lama Fermentasi dan Kadar Substrat Terhadap Produksi Etanol Pada Fermentasi Onggok oleh Saccharomyces cerevisiae, Fakultas MIPA, Universitas Brawijaya, Malang

Zheng, Y., Pan, Z., dan Zhang, R., 2009. Overview of biomass pretreatment for cellulosic ethanol production. Int $J$ Agric\& Biol Eng. 2(3), pp. 51-68 